\title{
Social deixis in Hadiyya
}

\section{Dereje Adane}

Department of English Language and Literature, Arba Minch University, Arba Minch, Ethiopia

\section{Email address:}

derejeadane@gmail.com

\section{To cite this article:}

Dereje Adane. Social Deixis in Hadiyya. International Journal of Language and Linguistics. Vol. 2, No. 5, 2014, pp. $301-304$. doi: $10.11648 /$ j.ijl1.20140205.12

\begin{abstract}
The concept of social deixis and its definition are stated by different scholars. Among these some are stated in this article in order to introduce the concept of social deixis to the reader. In the language, social deixis is expressed by both relational and absolute deictic terms.Relationaldeictic terms: age, marriage, circumcision status, and kinship are important constituents to show social deixis in the language.In Hadiyya, absolute deictic terms:office-related respect and mahaaraano 'people who have socio-cultural respect'are also used to show social deixis.
\end{abstract}

Keywords:Social, Deixis, Hadiyya, Relative Social Deixis, Absolute Social Deixis

\section{Social Deixis}

Jaszczolt (2002: 197) says, "Social deixis concerns social relationships between participants, their status and relations to the topic of discourse. Relationships that are relevant in this type of deixis include [those] between the speaker and the addressee, between other participants, the speaker and the object spoken about and so on." Levinson (1983: 89) and Jaszczolt (2002: 197) state that some of the grammatical devices that are used for the purpose of social deixis include pronouns of politeness, titles of addressee, kinship terms, and honorifics.

According to Traugolt and Dasher (2002: 228), there are various approaches to politeness. One involves conversational maxims (cf. Leech 1983). Another is to view politeness "in terms of universal strategies that diffuse "face threatening acts", as discussed by Brown and Levinson (1987).

There are two basic kinds of social deictic information which can occur in language (Levinson 1983: 90-91). The first conveys relational information. This may be between:

i. Speaker and referent (e.g. referent honorifics)

ii. Speaker and addressee (e.g. addressee honorifics)

iii. Speaker and bystander (e.g. bystander or audience honorifics)

iv. Speaker and setting (e.g. formality levels)" (1983: 90)

Such relational social deixis can be expressed by honorifics, but Levinson notes that there are other possibilities of social deixis which can be grammaticalized, e.g. via totemic relations, clan membership and so on.

The second type of social deixis is absolute (Levinson 1983: 91). Here there are forms which are absolutely reserved for certain speakers (cf. Fillmore 1975) or forms which are absolutely reserved for certain authorized recipients. The prototypical case involves speech by, or to, a royal person.

\subsection{Social Deixis in Hadiyya}

Levinson (1983: 63) says that "social deixis concerns the encoding of social distinctions that are relative to participantroles, particularly aspects of the social relationship holding between speaker and addressee(s) or speaker and some referent." To study social deixis in Hadiyya as it occurs in the speech between the participants during the communication act, one must have knowledge of the sociocultural background underlying the linguistic base.

Thus, in Hadiyya, social deixis can be expressed by both relational and absolute deictic terms. Age, marriage status, circumcision status and kinship are social deictic factors that can be grouped under relational social deixis. Officerelated respect (e.g. the chief) and mahaaraano 'people who have socio-cultural respect (a culture-specific term)' are absolute factors.

\subsubsection{Relational Social Deixis}

Respect to one's elders is one of the social norms in Hadiyya society. This social value is conveyed via honorific and plural agreement markers on the verbs, which are relational deictic expressions because they are relative 
to the speaker (cf. Table 1). These indicate that the speaker is respecting the addressee and/or the referent. The verb agreement marker of second person honorific is identical to
2PL (cf. example (1)). However, the third person has a different agreement form to show respect.

Table 1. The Hadiyya nominative, accusative and genitive pronouns

\begin{tabular}{|c|c|c|c|c|c|c|c|}
\hline Person & Gender/Honorific & Nominative & pronouns & Accusative & pronouns & Genitive & pronouns \\
\hline & & Singular & Plural & Singular & Plural & Singular & Plural \\
\hline 1 & Common & $a n$ & Nees & eese & neese & $i-$ & $n i-$ \\
\hline \multirow[t]{2}{*}{2} & Common & at & $k i ? n-u w w$ & keese & $k i ? n-u w w a$ & $k i-$ & $k i ? n-u w w-$ \\
\hline & Hon & $k i ? n$ & & ki?ne & & $k i ? n-$ & \\
\hline \multirow[t]{3}{*}{3} & M & $i t t^{\prime}$ & $\begin{array}{l}i t t^{\prime}-u w w / \\
i s s-u w w\end{array}$ & itt'o & $\begin{array}{l}i t t^{\prime}-u w w a l \\
\text { iss- } u w w a\end{array}$ & $i t t^{\prime}-$ & $\begin{array}{l}i t t^{\prime}-u w w- \\
/ i s s-u w w-\end{array}$ \\
\hline & $\mathrm{F}$ & is & $\begin{array}{l}i t t^{\prime}-u w w / \\
i s s-u w w\end{array}$ & ise & $\begin{array}{l}i t t^{\prime}-u w w a / \\
\text { iss- } u w w a\end{array}$ & $i s-$ & $\begin{array}{l}i t t^{\prime}-u w w- \\
/ i s s-u w w-\end{array}$ \\
\hline & Hon & iss & & isse & & iss- & \\
\hline
\end{tabular}

(1) a. kißn-uww haraččo iikk'-akko'o you.HON-PL pot break-SP.2PL 'You (PL) broke a pot.'

\section{b. ki?n haraččo iikk'-akko'o} you.HON pot break-SP.2PL

'You (HON) broke a pot.'

(2) an ki?n-e? weeš-ummo

I you.HON-ACC call-SP.1SG

'I called you (HON).'

(3) itt' ki?n-mine waar-ukko

he GEN.2SG.HON-house come-SP.3MSG

'He came to your (HON) house.'

Another social norm of Hadiyya society is marriagerelated. In Hadiyya marriage culture, a man's wife should show respect to all the family members of her husband and they respect her too. This respect is not based on their age. She never calls her husband's father and mother by their names. She cannot even utter the names of other things that start with the same sound(s) as her husband's father's name. For example, if her husband's father's name is "hallaama" his son's wife may not utter the word halliččo 'donkey' as it is, but must change the initial sound(s). For example, she may say iyyamiččo, which is associated with iyya 'carry'.

In addition to age and marriage, in Hadiyya, circumcision can also give rise to respect. In the culture the person who covers the eyes of the boy while he is being circumcised earns great respect from that boy.

In such cases, as above, this respect is again conveyed via honorific personal pronouns and verb agreement.

Kinship terms show social deixis in Hadiyya. These kinship terms cannot appear as absolute forms ("father" etc.), but must morphologically show a kinship relation to somebody ("my father" etc.) and hence are deictic. The Hadiyya kinship terms are presented in the following table.

Table 2.The Hadiyya kinship terms.

\begin{tabular}{llll}
\hline Kinship Terms & Gloss & Kinship Terms & Gloss \\
\hline Iyyumma & 'my mother' & is-ama & 'her mother' \\
iyyanna & 'my father' & is-anna & 'her father' \\
lobaayye & 'my eldest sister' & is-lobaayya & 'her eldest sister' \\
abbaayyo & 'my eldest brother' & is-lobabbayyo & 'her eldest brother' \\
amaayye & 'my aunt (maternal)' & is-amaayye & 'her aunt (maternal)' \\
eeše & 'my uncle (maternal)' & is-eešimma & 'her uncle (maternal)' \\
adaayye & 'my aunt (paternal)' & is-ada & 'her aunt (paternal)' \\
annabbo & 'my uncle (paternal)' & is-annabbaayyo & 'her uncle (paternal)' \\
\hline
\end{tabular}

Most of these terms are used both for $3^{\text {rd }}$-person reference and as terms of address. However, in Hadiyya, iyyumma 'my mother' and iyyanna 'my father' are not used as terms of address. Instead, the child calls his/her parents by maternal and paternal substitute nouns. ${ }^{1}$ In the language the most common substitute nouns are aačce, aayya, aadde for mother and $a b b a$ and $a b b a a b b a$ for father. Letus see some examples below.

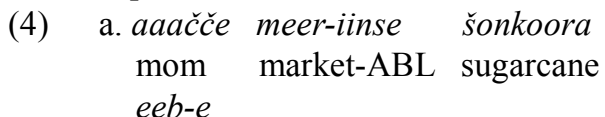

\footnotetext{
1 Note that the speaker may use his/her mother's or father's kinship term for $3^{\text {rd }}$-person reference while talking about them.
}

bring-2SG.IMP

'Mom, bring sugarcane from market!'

b. lobaayye eddečča aanš-e my older sister garment wash-2SG.IMP

'My older sister, wash the garment!'

c. amaayye soodo waar-e aunt tomorrow come-2SG.IMP

'Aunt (maternal), come tomorrow!'

d. eeshe t'orbere gob-e uncle ball sew-2SG.IMP

'Uncle (maternal), sew up the ball!'

The kinship terms in (4) above are serving as addressee ${ }^{2}$.

2 In Hadiyya, when the addressee is directly called, the final vowel is not 
The same kinship terms can also appear as a $3^{\text {rd }}$-person referent, as in (5).

$$
\begin{aligned}
& \text { (5) a. an annabbo iitt-oommo } \\
& \text { I uncle love-FUT.1SG } \\
& \text { 'I love my uncle (paternal).' } \\
& \text { b. an adaayye weesh-ummo } \\
& \text { I aunt call-SP.1SG } \\
& \text { 'I called my aunt (paternal).' }
\end{aligned}
$$

\subsubsection{Absolute Social Deixis}

In Hadiyya absolute social deixis expressed in two ways: formal or office-position related respect and mahaaraano 'people who have socio-cultural respect'. Formal or officeposition respect is expressed by the social dectics in Table 3 These forms are absolutely reserved for the authorized recipients, usually in formal speech for official purposes.

Table 3. The Hadiyya absolute social deictics

\begin{tabular}{lll}
\hline \multicolumn{2}{l}{ Absolute social deictic terms } & GLOSS \\
\hline 1. & hibbantakko?oo/haydantakko?oo & 'Your Excellency/Honor' \\
2. & hibbamakko?oo/haydamakko?oo & 'His/Her Excellency/Honor' \\
3. abbaačč & 'Mister' (Amharic ato) \\
4. $\quad$ aayyičč & 'Miss/Mrs'(Amharic \\
& & wäyzärit/wäyzäro) \\
\hline
\end{tabular}

In the above table the first two absolute deictics are formed from hibba 'charisma' and hayda 'honor'. These are used here as verbs (e.g. 'to give charisma'), and as such are followed by the passivizer $-m-$. Then SP.2HON takko?o and SP.3HON -akko?o are attached and the absolute deictics are formed by lengthening the final vowel $-o$. In the language hibbantakko?oo and haydantakko?oo are used interchangeably, and likewise hibbamakko?oo and haydamakko?oo.

The usage of these dectics in actual speech is that term 1 or 2 is followed by 3 or 4 , based on the addressee's gender and person. ${ }^{3}$ For example, for masculine $2^{\text {nd }}$ person you would say hibbantakko?oo/haydantakko?oo abbaačč ' $\mathrm{X}$ ' 'Your Excellency/Honor Mr. ' $\mathrm{X}$ '. See the following example.

(6) hibbamakko?oo abbaačč dilaam

his.Excellency Mr. Dilamo

soodo waaččamo waar-akkamo

tomorrow Wachemo come-FUT.3HON

'His Excellency Mr. Dilamo will come to Wachemo tomorrow.'

The second kind of absolute social deixis is shown by mahaaraano 'people who have socio-cultural respect'. In Hadiyya culture the procedure for being admitted to the status of mahaallano is too complex to discuss here. Ruther, my focus here is to show the connection between mahaaraano and social deixis. When someone gets mahaallaano 4 'socio-cultural royalty', every individual of the Hadiyya people will respect him irrespective of his age.

devoiced as usual. This is probably because the addressee-noun (vocative) is followed by a pause.

3 Numbers (1-4) in this context refer to the numerals in Table 3.

4 In Hadiyya mahaallano is given only for males.
This respect is manifested by their title, honorific personal pronoun and verb agreement. The names of titles and procedures for giving thetitles are discussed in detail by Eshetu et al. (2011). There are 13 such titles; some of them are: gadapp'i garaada, asmaačče, daddaaččo.See the following example.
(7) daddaačč
lopp'is beeballa
Daddaaččo (title) Lopp'iso yesterday
waar-akko?o
come-SP.3HON
'Daddach Lopiso came yesterday.'

\section{Summary}

In the Hadiyya language, social deixis is expressed by relational deictic terms. Social respect has several sources in Hadiyya society. It can come from age: in Hadiyya aged people get respect. Another thing that conveys respect is marriage status and circumcision status. Kinship terms also indicate the status relationship of the referent to the speaker. All these are used to indicate relational social deixis. Absolute deictic terms are also used to express social deixis. This absolute social deixis takes place during formal speech (to show office-related respect) and in any speech of speaker with/about mahaaraano 'people who have sociocultural respect'. These different types of social respect are expressed by honorific personal pronouns and honorific subject agreement on the verb.

\section{Abbreviation}

$\begin{array}{ll}- & \text { Morpheme boundary } \\ \cdot & \text { Portmanteau morphemes } \\ 1 & \text { First person } \\ 2 & \text { Second person } \\ 3 & \text { Third person } \\ \text { ABL } & \text { Ablative } \\ \text { ACC } & \text { Accusative } \\ \text { F } & \text { Feminine } \\ \text { FUT } & \text { Future } \\ \text { GEN } & \text { Genitive } \\ \text { HON } & \text { Honorific } \\ \text { IMP } & \text { Imperative } \\ \text { M } & \text { Masculine } \\ \text { PL } & \text { Plural } \\ \text { SG } & \text { Singular } \\ \text { SP } & \text { Simple past }\end{array}$

\section{References}

[1] Brown, Penelope and Stephen C. Levinson. 1987. Politeness: Some Universals in

[2] Language Usage. Cambridge: Cambridge University Press.

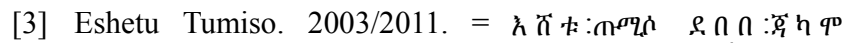

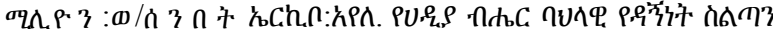

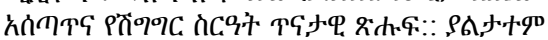


[4] Fillmore, Charles J. 1975. Santa Cruz Lectures on Deixis 1971. Bloomington: IULC.

[5] Jaszczolt, K.M. 2002. Semantics and Pragmatics: Meaning in Language and Discourse. London: Longman.

[6] Leech, Geoffrey N. 1983. Principles of Pragmatics. London: Longman.
[7] Levinson, Stephen C. 1983. Pragmatics. Cambridge: Cambridge University Press.

[8] Traugott, Elizabeth C. and Richard B. Dasher. 2002. Regularity in Semantic Change. Cambridge: Cambridge University Press. 